Sains Malaysiana 51(1)(2022): 1-13

http://doi.org/10.17576/jsm-2022-5101-01

\title{
Molecular Identification and Ochratoxigenic Potential of Black Aspergillus from Various Substrates and Indoor Environment
}

(Pengenalpastian Molekul dan Potensi Okratoksigen Aspergillus Hitam daripada Pelbagai Substrat dan Persekitaran Dalaman)

\author{
WARDAH ABDUL RAHMAN \& LATIFAH ZAKARIA*
}

\begin{abstract}
Aspergillus section Nigri or black Aspergillus is characterized by dark brown to black colonies. Several species of this group showcase the ability to produce ochratoxin A (OTA), contaminating various types of food and feed. This study was conducted to identify black Aspergillus isolated from rice, groundnuts, spices, corn grains, soil, and indoor environment and determine the ability of the isolates to produce OTA. Based on ITS, $\beta$-tubulin and calmodulin sequences, 177 isolates of black Aspergillus from various substrates and indoor environment were identified as A. niger, A. aculeatus, and A. tubingensis. By using two sets of primers to amplify two ochratoxin biosynthesis genes (PKS15KS and PKS15C-MeT genes), the OTA genes were detected in only six A. niger isolates from rice and indoor environment. These six A. niger isolates produced 8 to $308 \mu \mathrm{g} / \mathrm{g}$ of OTA as quantified using UPLC analysis. No OTA gene was detected in any of the A. tubingensis and A. aculeatus isolates. In conclusion, three black Aspergillus species, A. niger, A. aculeatus, and A. tubingensis, were identified from rice, groundnuts, spices, corn grains, soil, and indoor environment. Only six isolates of A. niger produced OTA indicating most of the A. niger isolates were non-OTA producers. These results could thus portray the occurrence of OTA in the field. Since both the number of isolates producing OTA and the levels of OTA production were low, it could be possibly assumed that the occurrence as well as the levels of OTA in the field are also low.
\end{abstract}

Keywords: Aspergillus aculeatus; A. niger; A. tubingensis; black Aspergillus; ochratoxin A

\section{ABSTRAK}

Aspergillus seksyen Nigri atau Aspergillus hitam dicirikan oleh koloni perang gelap ke hitam. Beberapa spesies kumpulan ini mempamerkan keupayaan menghasilkan okratoxin A (OTA) yang dapat dikesan dalam pelbagai jenis makanan dan makanan ternakan. Pengenalpastian ke tahap spesies Aspergillus hitam agak sukar kerana persamaan ciri makroskopik dan ciri mikroskopik. Dalam kajian ini, Aspergillus hitam dipencilkan daripada bahan makanan (beras, kacang tanah rempah dan bijirin jagung,), tanah dan persekitaran dalaman. Sebanyak 177 pencilan ini dikenal pasti sebagai A. niger, A. aculeatus dan A. tubingensis berdasarkan jujukan kawasan transkripsi penjarak dalaman (ITS), $\beta$-tubulin dan kalmodulin. Gen OTA hanya dikesan dalam enam pencilan A. niger yang diperoleh daripada beras dan persekitaran dalaman. Pencilan A. niger ini menghasilkan 8 hingga $308 \mu \mathrm{g} / \mathrm{g}$ OTA yang dikuantifikasi menggunakan analisis UPLC. Tiada gen OTA yang dikesan dalam pencilan A. tubingensis dan A. aculeatus. Kesimpulannya, tiga spesies Aspergillus hitam, A. niger, A. aculeatus dan A. tubingensis dikenal pasti daripada beras, kacang tanah, rempah, bijirin jagung, tanah dan persekitaran dalaman. Hanya 4.2\% daripada pencilan A. niger menghasilkan OTA dan ini menunjukkan kebanyakan pencilan A. niger bukan pengeluar OTA. Keputusan kajian dapat menggambarkan kejadian OTA di lapangan. Oleh kerana bilangan pencilan yang menghasilkan OTA dan tahap penghasilan OTA adalah rendah, kemungkinan kejadian dan tahap OTA di lapangan juga adalah rendah.

Kata kunci: Aspergillus aculeatus; Aspergillus hitam; A. niger; A. tubingensis; okratoksin A.

\section{INTRODUCTION}

Aspergillus section Nigri or black Aspergillus is a group of fungi consisting of various species such as $A$. niger,
A. tubingensis, A. carbonarius, A. foetidus, A. awamori, and $A$. japonicus (Samson et al. 2007). They can be seen naturally occurring on a variety of substrates including 
various types of food and feed, different types of soils and diverse indoor environments. Since black Aspergillus species showcase a cosmopolitan distribution, they can be seen growing in the tropical regions as well (Pitt \& Hocking 2009).

The toxigenic nature of some of the species of black Aspergillus is contributed by the production of ochratoxin A (OTA), commonly detected in different types of food and feed worldwide. OTA was either detected in the substrates or produced by the ochratoxigenic strains of black Aspergillus (Lasram et al. 2013; Leong et al. 2007). Black Aspergillus mediated OTA contamination might pose a potential risk to animal health and food safety owing to the ability of this mycotoxin to be transferred through the food chain. In case of large-scale production, the contamination with OTA can result in serious economic losses to livestock and agricultural products. Aspergillus carbonarius and A. niger are two most common ochratoxigenic species of black Aspergillus (Perrone et al. 2006). There are chances of occurrence of ochratoxigenic strains of these two species in Malaysia due to high relative humidity and temperature in tropical area which are well suited for growth of both the species as well as production of OTA. However, the optimum temperature of OTA production depends on several factors including the ochratoxigenic species, the commodities (substrates), temperature, relative humidity and water activity (Esteban et al. 2006; Magan \& Aldred 2005). Generally, temperature at $25-30{ }^{\circ} \mathrm{C}$, relative humidity of $88-95 \%$ and water activity greater than 0.78 are favourable for mycotoxigenic fungal growth and associated with mycotoxin production (Schatzmayr \& Streit 2013). Various substrates known to support the growth of black Aspergillus such as food and feed (rice, groundnuts, spices, and corn grains), and soils were included in this study. In Malaysia, groundnuts and spices are widely used as food commodities while corn grains are widely utilised as livestock feed. Black Aspergillus are common soil fungi associated with decomposition of plant materials, and some of the species are known to act as plant pathogen (Hong et al. 2013). Species of black Aspergillus can be found frequently growing in indoor environment (Ghosh et al. 2014; Varga et al. 2014), and some of these species are able to produce OTA (Samson et al. 2007).

The ability of black Aspergillus to produce OTA and the possibility of occurrence of more than one species in Malaysia necessitate the identification of various black Aspergillus species occurring in this region. The aim of the study was to identify the black Aspergillus species isolated from various substrates and indoor environments using PCR assay for ITS, $\beta$-tubulin and calmodulin sequences. The presence of OTA gene was also detected using PCR, and the amount of OTA produced by these isolates was quantified with the aid of ultra-high performance liquid chromatography with fluorescence detector (UPLC-FLR).

\section{Materials AND Methods}

A total of 177 isolates of black Aspergillus were used in the study. The isolates were either obtained from stock cultures of Plant Pathology Laboratory, School of Biological Sciences, Universiti Sains Malaysia or isolated from rice, groundnuts, spices, corn grains, agricultural soils and indoor environment. The isolates were identified as $A$. niger (153 isolates) and A. aculeatus (24 isolates) on the basis of morphological characteristics (Table 1). The molecular identity of these isolates was further established with the aid of PCR assay for ITS, $\beta$-tubulin, and calmodulin sequences.

\section{DNA EXTRACTION}

For DNA extraction, black Aspergillus isolates were cultured in malt extract broth in universal bottle in triplicates for each isolate. After 24-48 h, mycelia were harvested and dried on Whatman No.1 filter paper. The resulting mycelia were stored in a freezer for overnight. This was followed by freeze-drying the samples for $48 \mathrm{~h}$ using a Labconco freeze dryer. Further, the freeze-dried mycelia were ground into fine powder in liquid nitrogen using sterile mortar and pestle. Aproximately $60 \mathrm{mg}$ of the powdered mycelia were transferred to $1.5 \mathrm{~mL}$ microcentrifuge tubes. DNA extraction was performed using DNeasy Plant Mini Kit (Qiagen, Germany) according to the manufacturer's protocol.

\section{PCR AMPLIFICATION}

For PCR amplification, primers ITS1 (5'-TCC GTA GGT GAA CCT GCG G-3') and ITS4 (5' -TCC TCC GCT TAT TGA TAT GC-3') were used for ITS regions (White et al. 1990), primers Bt2a (5'-GGT AAC CAA ATC GGT GCT GCT TTC3') and Bt2b (5'-ACC CTC AGT GTA GTG ACC CTT GGC-3') were used for $\beta$-tubulin gene (Glass \& Donaldson 1995), and primers cmd5 (5'-CCGAGTACAAGGAGGCCTTC-3') and cmd6 (5'-CCGATAGAGGTCATAACGTGG-3') were used for calmodulin gene (Hong et al. 2006).

PCR reactions were carried out using a reaction cocktail $(25 \mu \mathrm{L})$ consisting $4 \mu \mathrm{L} 5 \mathrm{X}$ green buffer, $4 \mu \mathrm{L}$ $25 \mathrm{mM} \mathrm{MgCl}, 0.5 \mu \mathrm{L} 10 \mu \mathrm{M}$ dNTP mix (Promega, USA), $4 \mu \mathrm{L}$ each primer $(5 \mathrm{mM})$ and $0.15 \mu \mathrm{L} 5 \mathrm{U} / \mu \mathrm{L}$ GoTaq $^{\circledR}$ (Promega, USA). An amount of $0.3 \mu \mathrm{L}$ DNA template was added for the amplifications of ITS regions and $\beta$-tubulin, and $0.1 \mu \mathrm{L}$ DNA template was added for the amplification of calmodulin. The final reaction volume was adjusted to $25 \mu \mathrm{L}$ by addition of required amount of deionised distilled water. 
TABLE 1. List of black Aspergillus isolates with their morphological identity

\begin{tabular}{|c|c|c|}
\hline Isolates & Substrate & Morphologically identified species \\
\hline AP1R-AP33R & Rice & A. niger \\
\hline AP34R & Rice & A. aculeatus \\
\hline AP35R-AP39R & Rice & A. niger \\
\hline AR40R-AR41R & Rice & A. niger \\
\hline $\mathrm{AC} 42 \mathrm{R}-\mathrm{AC} 43 \mathrm{R}$ & Rice & A. niger \\
\hline AM44R-AM46R & Rice & A. niger \\
\hline AN47R-AN48R & Rice & A. niger \\
\hline AW49R & Rice & A. aculeatus \\
\hline AS50R & Rice & A. niger \\
\hline AS51R-AS52R & Rice & A. aculeatus \\
\hline AW53R & Rice & A. aculeatus \\
\hline AW54R & Rice & A. niger \\
\hline AW55R & Rice & A. aculeatus \\
\hline AP56R & Rice & A. aculeatus \\
\hline AW57R & Rice & A. niger \\
\hline AW58R-AW60R & Rice & A. aculeatus \\
\hline AP61R-AP62R & Rice & A. aculeatus \\
\hline AS63R & Rice & A. aculeatus \\
\hline AW64R-AW66R & Rice & A. aculeatus \\
\hline AA67N & Groundnuts & A. niger \\
\hline AA68N & Groundnuts & A. aculeatus \\
\hline AA69N-AA71N & Groundnuts & A. niger \\
\hline AA72N & Groundnuts & A. aculeatus \\
\hline AA73N-AA82N & Groundnuts & A. niger \\
\hline AP83N & Groundnuts & A. niger \\
\hline AP84D-AP105D & Spices & A. niger \\
\hline AC106B-AC107B & Indoor environment & A. niger \\
\hline AD108B & Indoor environment & A. niger \\
\hline AK109B & Indoor environment & A. aculeatus \\
\hline AM110B-AM111B & Indoor environment & A. niger \\
\hline AN112B & Indoor environment & A. aculeatus \\
\hline AP113B-AP128B & Indoor environment & A. niger \\
\hline AP129B & Indoor environment & A. aculeatus \\
\hline AP130B & Indoor environment & A. niger \\
\hline AS131B & Indoor environment & A. niger \\
\hline AS132B & Indoor environment & A. aculeatus \\
\hline AS133B & Indoor environment & A. niger \\
\hline AT134B-AT137B & Indoor environment & A. niger \\
\hline AP138O-AP1550 & Corn grains & A. niger \\
\hline AM156O-AM163O & Corn grains & A. niger \\
\hline AP164S & Soil from vegetable farm & A. aculeatus \\
\hline AP165S-AP166S & Soil from oil palm plantation & A. niger \\
\hline AP167S-AP168S & Soil from paddy field & A. niger \\
\hline AP169S-AP177S & Soil from oil palm plantation & A. niger \\
\hline
\end{tabular}


PCR was performed in a thermal cycler (BioRad Mycycler $^{\circledR}$ ) with the following PCR cycles for the amplification of ITS regions: Initial denaturation at 95 ${ }^{\circ} \mathrm{C}$ for $5 \mathrm{~min}, 30$ cycles with each cycle consisting of denaturation at $95{ }^{\circ} \mathrm{C}$ for $30 \mathrm{~s}$, annealing at $58^{\circ} \mathrm{C}$ for 30 $\mathrm{s}$ and extension at $72{ }^{\circ} \mathrm{C}$ for $1 \mathrm{~min}$, with final extension at $72{ }^{\circ} \mathrm{C}$ for $5 \mathrm{~min}$. For $\beta$-tubulin, PCR cycles were as follows: initial denaturation at $94{ }^{\circ} \mathrm{C}$ for $5 \mathrm{~min}, 35$ cycles consisting of denaturation at $58.6{ }^{\circ} \mathrm{C}$ for $30 \mathrm{~s}$, annealing at $58.6{ }^{\circ} \mathrm{C}$ for $30 \mathrm{~s}$ and extension at $72{ }^{\circ} \mathrm{C}$ for $1 \mathrm{~min}$, with final extension at $72{ }^{\circ} \mathrm{C}$ for $5 \mathrm{~min}$. For calmodulin, PCR was carried out with initial denaturation at $95{ }^{\circ} \mathrm{C}$ for 5 min, followed by 35 cycles consisting of denaturation at $95{ }^{\circ} \mathrm{C}$ for $30 \mathrm{~s}$, annealing at $60{ }^{\circ} \mathrm{C}$ for $30 \mathrm{~s}$ and extension at $72{ }^{\circ} \mathrm{C}$ for $30 \mathrm{~s}$. The final extension step was carried out at $72{ }^{\circ} \mathrm{C}$ for $5 \mathrm{~min}$.

PCR products for all the DNA regions were separated on a $1 \%$ agarose gel, run in $1 \mathrm{X}$ Tris-borate EDTA buffer for $90 \mathrm{~min}$ at $90 \mathrm{~V}$ and $400 \mathrm{~mA}$. The DNA bands were visualised with the aid of Florosafe DNA Stain (1st Base).

\section{SEQUENCE ANALYSIS AND PHYLOGENETIC ANALYSIS}

DNA sequencing on the PCR products was outsourced. The resulting sequences were aligned using ClustalW and edited manually by Molecular Evolutionary Genetic Analysis (MEGA 5) software to create consensus sequence (Tamura et al. 2011). BLAST analysis was used to compare the consensus sequences with the sequences in database of GenBank (http://www.ncbi.nlm.nih.gov). Species were identified on the basis of BLAST results showing $97-100 \%$ similarity with the sequences in the GenBank.

Multiple sequence alignment based on combined sequences of ITS, $\beta$-tubulin and calmodulin sequences of all isolates were generated to construct a phylogenetic tree using MEGA5 software. Phylogenetic relationships were analysed using Maximum Likelihood (ML), a character-based method. Kimura 2-parameter model was used to construct the ML tree. Model test was run to find the best substitutions DNA models and from the model test result, the lowest AIC scores (Akaike Information Criterion) was chosen. The reliability of the ML tree was estimated using bootstrap method with 1000 replicates. For phylogenetic analysis, complete-deletion option was selected and all positions containing gaps and missing data were eliminated. Ex-type strains for each species were also included for comparison (Samson et al. 2014). To root the tree, Aspergillus flavus (NRRL 1957) was used as the outgroup.

\section{OCHRATOXIN PRODUCTION \\ PCR AMPLIFICATION OF OTA GENE}

PCR amplification of OTA gene was performed after molecular identification of the black Aspergillus isolates of which three species were identified, A.niger, $A$. aculeatus, and $A$. tubingensis. A total of 153 isolates of $A$. niger, 24 isolates of $A$. aculeatus and nine isolates of $A$. tubingensis were used for PCR amplification of the OTA gene and quantification of OTA. Two different primer sets, namely PKS15KS primers and PKS15C-MeT primers were used to detect OTA gene (An15g07920) (Kim et al. 2014). PKS15KS primer set consisted of PKS15KS-f (5'-CAA TGC CGT CCA ACC GTA TG-3') and PKS15KS-r (5'-CCT TCG CCT CGC CCG TAG-3'), while PKS15C-MeT primer set consisted of PKS15C-MeT-f (5'-GCT TTC ATG GAC TGG ATG-3') and PKS15C-MeT-r (5'-CAT TTC GTT GAT CCC ATC G-3'). These primers were used to amplify the putative $P K S$ gene fragments of An $15 \mathrm{~g} 07920$ gene that are involved in OTA biosynthesis. The PKS15KS primer set was used to amplify DNA fragment corresponding to $\beta$-ketoacyl synthase (KS) domain, while PKS15C-MeT primer set was used for DNA fragment corresponding to C-methyltransferase (C-Met) domain. Both KS and C-Met domains are reported to be present in the hypothetical protein encoded by An15g07920 gene (Ferracin et al. 2012).

The amplification of OTA genes was performed separately in a $25 \mu \mathrm{L}$ reaction mixture consisting of 4 $\mu \mathrm{L} 5 \mathrm{X}$ green buffer, $4 \mu \mathrm{L} 25 \mathrm{mM} \mathrm{MgCl}, 0.5 \mu \mathrm{L} 10 \mu \mathrm{M}$ dNTP mix (Promega), $4 \mu \mathrm{L}$ each primer, $0.15 \mu \mathrm{L} 5 \mathrm{U} /$ $\mu \mathrm{L} \operatorname{GoTaq}^{\circledR}$ (Promega) and $0.1 \mu \mathrm{L}$ DNA template. The final volume of reaction mixture was adjusted to $25 \mu \mathrm{L}$ with deionised distilled water. Sterile deionised water was used as a negative control. PCR was performed as described above with following PCR cycle conditions: initial denaturation at $95{ }^{\circ} \mathrm{C}$ for $4 \mathrm{~min}, 30$ amplification cycles consisting of denaturation at $95{ }^{\circ} \mathrm{C}$ for $1 \mathrm{~min}$, annealing at $55^{\circ} \mathrm{C}$ for $1 \mathrm{~min}$ and extension at $72{ }^{\circ} \mathrm{C}$ for $1 \mathrm{~min}$, followed by final extension at $72^{\circ} \mathrm{C}$ for $7 \mathrm{~min}$.

\section{AGAR PLUG METHOD FOR IN VITRO MYCOTOXIN PRODUCTION}

Black Aspergillus isolates were inoculated at three points on Czapek Yeast Extract (CYA) using standard agar plug method (Bragulat et al. 2001) with modifications. After 7 days of inoculation, all the three agar plugs were carefully removed from each plate with the help of an $8 \mathrm{~mm}$ cork borer and transferred to a McCartney bottle. 
The agar plugs from each isolate were homogenised in $0.5 \mathrm{~mL}$ methanol and incubated at room temperature for $60 \mathrm{~min}$. The resulting extracts were filtered by passing through syringe filters (PTFE) with a diameter of 25 $\mathrm{mm}$. These were further injected into $2 \mathrm{~mL}$ glass screw neck vials (Waters, USA). The final solution from each isolate was stored at $4{ }^{\circ} \mathrm{C}$ until analysed using ultrahigh performance liquid chromatography (UPLC) with fluorescence detector. OTA production by each isolate was repeated twice.

\section{PREPARATION OF OTA STANDARD}

OTA was commercially purchased from Sigma Chemical Cp. (St Louis, MO, USA). Standard stock solution $(1000 \mu \mathrm{g} / \mathrm{g})$ was prepared in $1 \mathrm{~mL}$ methanol and stored at $8{ }^{\circ} \mathrm{C}$ until used. From this, five working stock solutions $(2,4,6,8$ and $10 \mu \mathrm{g} / \mathrm{g})$ were prepared in methanol and stored at $4{ }^{\circ} \mathrm{C}$ until analysed using UPLC.

\section{UPLC-FLR ANALYSIS}

UPLC system consisting of Waters Acquity UPLC ${ }^{\circledR}$ binary pump equipped with Waters Acquity UPLC ${ }^{\circledR}$ FLR detector was used for quantification of OTA produced by isolates. For detection, the excitation and emission maxima were set at 330 and $460 \mathrm{~nm}$ wavelength, respectively. Chromatographic separations were carried out on a C18 reversed-phase column $(2.1 \times 100 \mathrm{~mm}, 1.7$ $\mu \mathrm{m}$ ) (Waters, USA) with isocratic programme of $57 \%$ acetonitrile $\left(\mathrm{CH}_{3} \mathrm{CN}\right), 41 \%$ water and $2 \%$ acetic acid (filtered through a PTFE syringe filter). The separation was performed at a flow rate of $0.2 \mathrm{~mL} / \mathrm{min}$ with total run time of $4 \mathrm{~min}$. For OTA quantification, peak height of the sample was compared with the calibration curve of the standards.

\section{RESULTS AND DISCUSSION}

PCR amplification of ITS regions and calmodulin gene produced a fragment of approximately $600 \mathrm{bp}$ of morphologically identified $A$. niger (154 isolates) and A. aculeatus (24 isolates). The amplification reaction for $\beta$-tubulin gene produced a band of $550 \mathrm{bp}$ for all the isolates morphologically identified as $A$. niger and $A$. aculeatus.

BLAST search results for sequences of ITS regions, $\beta$-tubulin, and calmodulin expressed as percentage of sequence similarity, and the newly assigned identities for various isolates are shown in Table 2. BLAST search for the sequences of the three markers confirmed the identity of 144 isolates of $A$. niger. However, nine isolates morphologically identified as $A$. niger showed molecular identity of $A$. tubingensis. Molecular study also confirmed the identity of 24 isolates morphologically identified as $A$. aculeatus.

TABLE 2. Percentage of sequence similarity and identity assigned to morphologically identified A. niger and A. aculeatus isolates obtained from various substrates and indoor environment

\begin{tabular}{|c|c|c|c|c|}
\hline \multirow{2}{*}{$\begin{array}{l}\text { Morphological } \\
\text { identification }\end{array}$} & \multicolumn{3}{|c|}{ Sequence similarity (\%) } & \multirow{2}{*}{ Identity assigned } \\
\hline & ITS & $\beta$-tubulin & Calmodulin & \\
\hline $\begin{array}{l}\text { A. aculeatus } \\
\text { (24 isolates) }\end{array}$ & $\begin{array}{c}\text { A. aculeatus } \\
\text { (99-100) }\end{array}$ & $\begin{array}{c}\text { A. aculeatus } \\
\text { (98-100) }\end{array}$ & $\begin{array}{c}\text { A. aculeatus } \\
\text { (97-99) }\end{array}$ & A. aculeatus \\
\hline $\begin{array}{c}\text { A. niger } \\
\text { (144 isolates) }\end{array}$ & $\begin{array}{l}\text { A. niger } \\
(99-100)\end{array}$ & $\begin{array}{l}\text { A. niger } \\
(98-99)\end{array}$ & $\begin{array}{l}\text { A. niger } \\
(98-100)\end{array}$ & A. niger \\
\hline $\begin{array}{c}\text { A. niger } \\
\text { (9 isolates) }\end{array}$ & $\begin{array}{c}\text { A. tubingensis } \\
\text { (99) }\end{array}$ & $\begin{array}{l}\text { A. tubingensis } \\
\text { (99) }\end{array}$ & $\begin{array}{c}\text { A. tubingensis } \\
\text { (97-99) }\end{array}$ & A. tubingensis \\
\hline
\end{tabular}


Maximum likelihood tree generated using combined sequences of ITS, $\beta$-tubulin and calmodulin is shown in Figure 1. Isolates from the same species were clustered in the same clade and not grouped according to the locations or substrate. The outgroup, A. flavus (NRRL 1957 ) formed separate clade. Isolates of $A$. niger and $A$. tubingensis were grouped in the same main clade (Clade
B) but separated into two sub-clades (B1 and B2). The grouping indicated close relationship between $A$. niger and $A$. tubingensis isolated from different substrates (rice, groundnuts, spices, corn grains, and agricultural soils) including isolates from indoor environment. Isolates of $A$. aculeatus formed separate clade (Clade A) from A. niger and A. tubingensis.

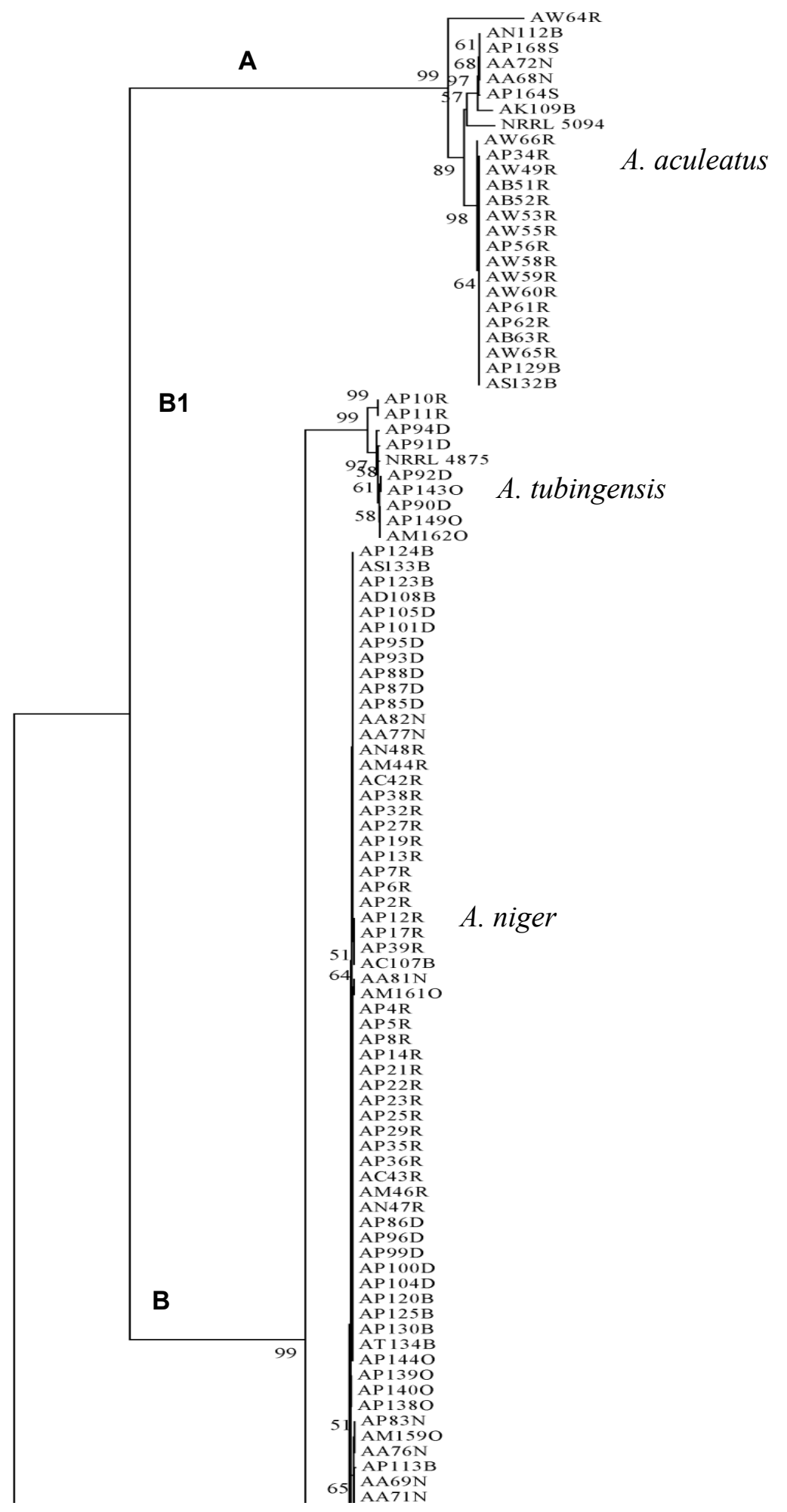




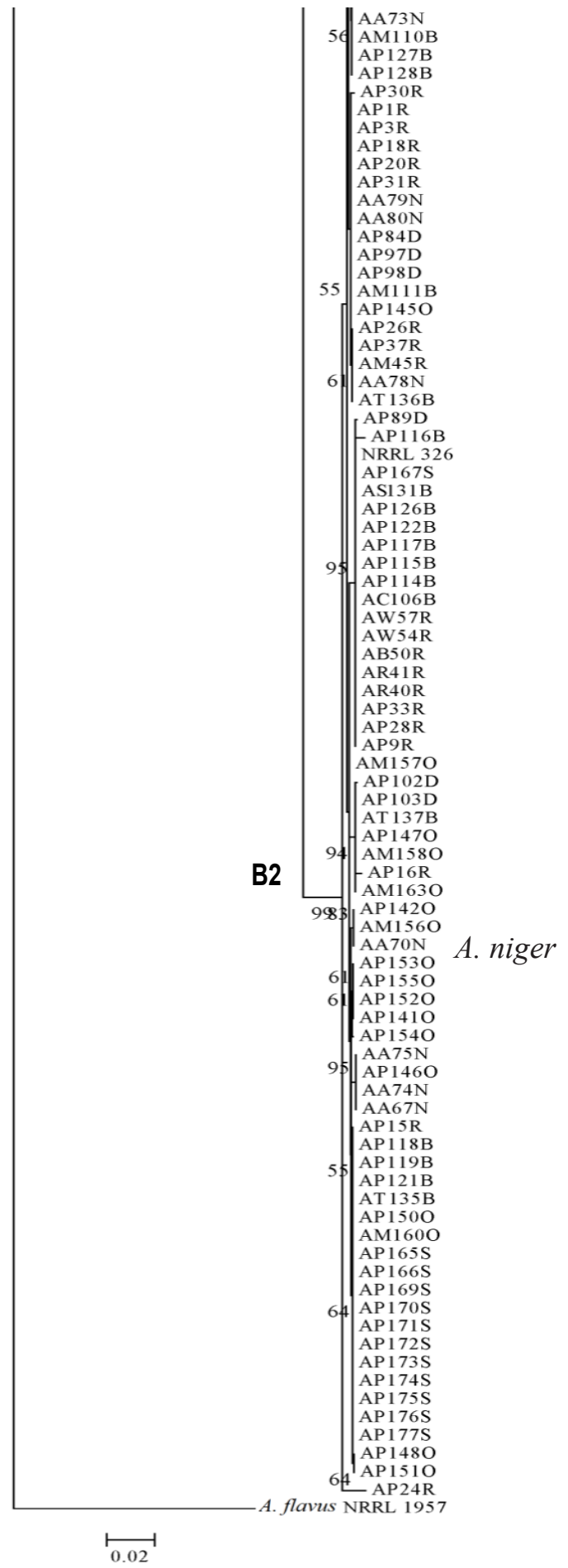

FIGURE 1. Maximum Likelihood tree generated based on combined sequences of ITS, $\beta$-tubulin and calmodulin of black Aspergillus. Bootstrap values higher than $50 \%$ are shown next to the branches. Aspergillus flavus is the outgroup 
Aspergillus niger was found to be the most commonly occurring species of black Aspergilli in Malaysia which was recovered from various types of substrates and indoor environment. Species of the genus Aspergillus including $A$. niger are moderately xerophilic owing to their ability to survive in harsh conditions such as high temperature and low water availability (Pettersson \& Leong 2011; Pitt \& Hocking 2009). The high prevalence of $A$. niger observed in the present study might be contributed by its natural tendency to grow well in warm places with high temperature such as Malaysia. In addition to this, black conidia produced by $A$. niger provide protection against UV light and sunlight (Pitt \& Hocking 2009). All these features provide an advantage to A. niger to compete with other black Aspergillus as well as other fungal species.

Most of the food and feed included in this study were generally dry in nature having low moisture content. There are several reports where rice, groundnuts, spices and corn grains are categorized as dried food and feed having low water content (Beuchat 1979; Pitt \& Hocking 2009). The dried substrates thus provide a habitat ideal for survival and growth of $A$. niger conidia. Aspergillus niger has been frequently isolated from stored and post-harvest products including onion bulbs and maize (Nyongesa et al. 2015; Shehu \& Muhammad 2012). Thus, the occurrence of $A$. niger on different substrates might indicate the possibility of $A$. niger contamination, particularly in the agricultural crops in the field. It is one of the ubiquitous fungi that can be found growing in the soil, thus it can act as a saprophyte.

In case of indoor environment, $A$. niger is a prevalent indoor fungus that can be easily found in any type of buildings. The findings of the present study were in accordance with the previous findings where $A$. niger was found prevalent in different types of soil and indoor environment such as indoor air in a library (Abdullah \& Muhammed 2011; Ghosh et al. 2014; Leong et al. 2007;
Varga et al. 2014; Zarei et al. 2016). The prevalence of $A$. niger in such environments could be possibly explained by the ability of its conidia to remain dormant in soil and air during the unfavorable growth conditions. Thus, the conidia of $A$. niger are well suited for airborne dispersal and could grow upon availability of favorable environmental conditions (Hayer et al. 2014).

Only nine isolates were identified as $A$. tubingensis in this study. Although A. tubingensis was not prevalent in this study, this species has been reported as a common contaminant found in food products, feed, soils and indoor air (Garcia-Cela et al. 2014; Lopez-Mendoza et al. 2009; Medina et al. 2005; Varga et al. 2014). In this study, $A$. tubingensis shared several substrates with $A$. niger such as rice, spices and corn grains. Thus, the presence of both the species on the same substrate is a common occurrence. Growth and ecological conditions suitable for $A$. tubingensis also show similarity with $A$. niger. However, A. tubingensis was not prevalent in the present study, and this observation lacks a possible explanation. The only possible explanation could be dry nature of the substrates available for growth. There are several reports where $A$. tubingensis preferred cooler temperature like northern Italy where grapes are planted (Spadaro et al. 2012). Nevertheless, both A. niger and A. tubingensis were found occurred together on the same substrates such as grapes, raisins, cashew nuts, cocoa beans and herbal tea (Bisbal et al. 2009; Lamboni et al. 2016; Palumbo et al. 2011; Vitale et al. 2012).

The presence of OTA gene in various isolates was studied by PCR of which 776 bp and 998 bp fragments were obtained, corresponding to $\mathrm{KS}$ and C-MeT domains, respectively. Only six isolates of $A$. niger showed the presence of KS and C-MeT domains. These isolates were subjected to OTA quantification using UHPLC-FLR. The results of UHPLC-FLR analysis are summarised in Table 3. The six isolates of $A$. niger showed OTA production levels of $0.26-3.26 \mu \mathrm{g} / \mathrm{g}$.

TABLE 3. Concentration of OTA produced by six isolates of $A$. niger isolated from rice and indoor environment

\begin{tabular}{ccc}
\hline Isolates & Sources & Concentration $(\mu \mathrm{g} / \mathrm{g})$ \\
\hline AP33R & Rice & 2.26 \\
AR40R & Rice & 1.21 \\
AW57R & Rice & 0.26 \\
AC106B & Indoor environment & 3.26 \\
AP126B & Indoor environment & 2.56 \\
AS131B & Indoor environment & 2.98 \\
\hline
\end{tabular}


UPLC analysis showed that $A$. niger isolates from rice produced OTA in the range of $0.26-2.26 \mu \mathrm{g} / \mathrm{g}$. This was lower as compared to OTA produced by $A$. niger isolates obtained from indoor environment which showed OTA concentrations of 2.56-3.26 $\mu \mathrm{g} / \mathrm{g}$. Sánchez-Hervás et al. (2008) classified OTA producers having OTA production in the range of $10-100 \mu \mathrm{g} / \mathrm{g}$ as moderately toxigenic isolates. According to the study of Belli et al. (2004), OTA production levels of 0.0-2.5 $\mu \mathrm{g} / \mathrm{g}$ were regarded as low. Based on these classifications, the six OTA producing $A$. niger isolates in the present study can be classified as low toxigenic isolates that produce low concentrations of OTA.

OTA produced by $A$. niger isolates obtained from rice in the present study was similar to OTA produced by black Aspergillus isolated from rice in Thailand, which produced $0.20-205.52 \mathrm{ng} / \mathrm{g}$ of OTA as studied using HPLC (Kittikamhaeng \& Dachoupakan 2011). Even though only three isolates of $A$. niger were found to produce OTA, there is a possibility of rice contamination with OTA. Natural occurrence of OTA in rice has been previously reported in Brazil (Almeida et al. 2012) and India (Priyanka et al. 2014). In Malaysia, OTA has been detected in cereals including rice and quantified by HPLC in two separate studies showing OTA levels of 0.03-5.32 $\mathrm{ng} / \mathrm{g}$ (Rahmani et al. 2010) and 0.2-4.34 ng/g (Soleimany et al. 2012). In another study, OTA production was also reported in red rice with concentrations in the range of $0.23-2.48 \mu \mathrm{g} / \mathrm{kg}$ (Samsudin \& Abdullah 2013).

Since OTA production was detected for $A$. niger isolated from rice, there is a possibility of OTA contamination which might have occurred before harvesting, in between harvesting and drying or during storage (Zheng et al. 2006). Therefore, several measures should be taken to minimize the risk of OTA contamination such as application of Good Agricultural Practise and Good Manufacturing Practise during growth, harvesting and storage of rice. Creating food safety awareness among rice farmers and producers might be instrumental in controlling the entry of contaminated food into dietary channel of humans and animals. Training programs involving direct communication between researchers, farmers and relevant government agencies should be routinely conducted to increase understanding regarding the importance of controlling contamination of rice with OTA and other mycotoxins. Since there are chances of OTA contamination at any stage, regular monitoring should be done at every stage so that necessary steps can be taken at the earliest.

For A. niger isolates obtained from indoor environment, only three isolates showed OTA production in the range of $2.56-3.26 \mu \mathrm{g} / \mathrm{g}$. Aspergillus are wellknown indoor fungi and inhalation of ochratoxigenic A. niger may cause harmful effects in humans (Abbott 2002). In two separate studies, Di-Paolo et al. (1994) and Richard et al. (1999) reported the possibility of ochratoxigenic $A$. niger having detrimental health effects. Current research studies majorly focus on diversity and distribution of black Aspergillus without much interest in OTA quantification. Consequently, studies on the production of OTA by black Aspergillus from indoor environment are quite limited and poorly understood (Varga et al. 2014; Wardah et al. 2012).

High prevalence of $A$. niger and low levels of OTA production observed in the present study were similar to the findings of Samsudin and Abdullah (2013), where $A$. niger was majorly found to be a non-OTA producer. In Taiwan, A. niger was commonly found in green coffee beans but it lacked any OTA production (Leong et al. 2007). Fredj et al. (2009) reported low levels of OTA production by $A$. niger aggregate (consisting of $A$. niger and $A$. tubingensis). The OTA production in grapes was reported only $5 \%$ of $A$. niger strains while $80 \%$ of $A$. carbonarius strains produced OTA. In Malaysia, some reports on natural occurrence of OTA in association with food products such as white pepper and spices which was probably contributed by OTA-producer, $A$. niger (Ali et al. 2015; Jalili et al. 2010).

The absence of both KS and C-MeT domains and OTA production in 136 isolates of $A$. niger indicated that most of $A$. niger isolates from rice, groundnuts, spices, corn grains, soil and indoor environment were non-OTA producers. Serra et al. (2006) and Susca et al. (2016) described $A$. niger as a low OTA producer while Benford et al. (2001) described it as a less important OTA producer. Existence of non-OTA producing strains of $A$. niger has been previously reported in animal feed, corn and soil (Accensi et al. 2004). The inability of $A$. niger isolates to produce OTA might be caused by gene deletions within the OTA biosynthetic gene clusters (Massi et al. 2016). Frisvad et al. (2007) suggested that the occurrence of silent genes or mutations in the functional or regulatory genes could be responsible for the loss of OTA production. Similarly, a study by Gallo et al. (2012) showed that deletion of a gene from $A$. carbonarius isolate eliminated its ability to produce OTA.

In the present study, A. aculeatus was isolated from various sources such as rice, groundnuts, soils and indoor environment. Aspergillus aculeatus is also a common contaminant of food and feed that can also be obtained from indoor environment and soil (Dalcero et al. 2002; Kim et al. 2013; Saadabi 2011; Saadullah 2013; Spadaro 
et al. 2012; Teh \& Latiffah 2015). However, its prevalence was low as compared to $A$. niger. There is a possibility that the substrates of $A$. aculeatus are not as wide as $A$. niger. Besides, there is limited information available for A. aculeatus, and it is often misidentified as $A$. japonicus (Parenicová et al. 2001). No OTA gene and OTA production was detected in 24 isolates of $A$. aculeatus obtained from various substrates, indicating non-OTA producing nature of this species. In a similar study by Nugroho et al. (2013), A. aculeatus was classified as non-OTA producer.

No OTA production was detected in any of the $A$. tubingensis isolates obtained from rice, spices and corn grains. Therefore, it is regarded as a non-OTA producer. This finding corroborated well with the findings of Frisvad et al. (2007), Nielsen et al. (2009) and Varga et al. (2011). However, there are reports for OTA production by A. tubingensis (Medina et al. 2005; Perrone et al. 2006). These contrasting reports might be due to misidentification of the species. For instance, six A. tubingensis strains deposited in international culture collections by Perrone et al. (2006) were initially described as OTA producer, but were again identified as non-OTA producer by Storari et al. (2012). Moreover, there are many studies where OTA producing strains were denoted by $A$. niger aggregate or black Aspergillus, which was used for both $A$. niger and A. tubingensis. UPLC analysis showed that only $\operatorname{six} A$. niger isolates produced OTA but at low levels. The low levels of OTA production indicated that even though $A$. niger is a prevalent species, but the ochratoxigenic strains of this species are not that prevalent in Malaysia. The differences in the ability of $A$. niger isolates to produce OTA might be caused by the variation in the isolates arising due to differences in the type of substrate as well as the location of occurrence. The absence of OTA genes and OTA production in A. tubingensis and A. aculeatus isolates in the present study classified these isolates as non-OTA producers. This infrequent occurrence of OTA producing black Aspergillus in various substrates and indoor environment might suggest low prevalence of ochratoxigenic forms of black Aspergillus in this area. However, accumulation of ochratoxin even at low levels, especially in food might have negative impact on human health.

\section{CONCLUSION}

The results of this study confirmed three black Aspergillus species, A. niger, A. aculeatus and $A$. tubingensis, were identified from various substrates and indoor environment. Correct species identification of black Aspergillus is required to provide early information regarding OTA contamination. The occurrence of black Aspergillus, particularly A. niger, is relatively high in Malaysia due to favourable growth conditions, but only $4.2 \%$ of the $A$. niger isolates produced OTA indicating most of the $A$. niger isolates were non-OTA producers. Since the levels of OTA production were low, it might indicate low occurrence and production of OTA in the field. Even though A. niger is not a main OTA-producer, special attention should be given to this species as it is a known for fumonisin $\mathrm{B}_{2}$ production, another mycotoxin having the ability to cause harmful health effects in humans and animals.

\section{ACKNOWLEDGEMENTS}

Authors would like to thank Dr. Baharuddin Salleh for his support and advice during the research work. This work was supported in part by Research University Grant (1001/PBIOLOGY/811307) from Universiti Sains Malaysia.

\section{REFERENCES}

Abbott, S.P. 2002. Mycotoxins and indoor molds. Indoor Environment Connections 3(4): 14-24.

Abdullah, S.K. \& Muhammed, A.A.H. 2011. Prevalence of black aspergilli in soil at vineyards in Duhok, Kurdistan Region of Iraq. The 4th International Scientific Conference of Salahaddin University-Erbil, Iraq. pp. 966-969.

Accensi, F., Abarca, M.L. \& Cabañes, F.J. 2004. Occurrence of Aspergillus species in mixed feeds and component raw materials and their ability to produce ochratoxin A. Food Microbiology 21(5): 623-627.

Ali, N., Hashim, N.H. \& Shuib, N.S. 2015. Natural occurrence of aflatoxins and ochratoxin A in processed spices marketed in Malaysia. Food Additives \& Contaminants: Part A, Chemistry, Analysis, Control, Exposure \& Risk Assessment 32(4): 518-532.

Almeida, M.I., Almeida, N.G., Carvalho, K.L., Gonçalves, G.A.A., Silva, C.N., Santos, E.A. \& Vargas, E.A. 2012. Ochratoxin A, zearalenone, deoxynivalenol, and citreoviridin in rice in Brazil. Food Additives \& Contaminants: Part A 29(4): 694-703.

Belli, N., Pardo, E., Mar, S., Farr, G., Ramos, A.J. \& Sanchis, V. 2004. Occurrence of ochratoxin A and toxigenic potential of fungal isolates from Spanish grapes. Journal of the Science of Food and Agriculture 84(6): 541-546.

Benford, D., Boyle, C., Dekant, W., Fuchs, E., Gaylor, D.W., Hard, G. \& Walker, R. 2001. Ochratoxin A Safety Evaluation of Certain Mycotoxins in Food. WHO Food Additives Series 47. FAO Food and Nutrition Paper 74, Geneva: World Health Organization. pp. 281-415.

Beuchat, L.R. 1979. Survival of conidia of Aspergillus flavus in dried foods. Journal of Stored Products Research 15(1): 25-31. 
Bisbal, F., Vicente, J., Daniel, G. \& Martínez-culebras, P.V. 2009. ITS-RFLP characterization of black Aspergillus isolates responsible for ochratoxin A contamination in cocoa beans. European Food Research and Technology 229: 751-755.

Bragulat, M.R., Abarca, M.L. \& Cabanes, F.J. 2001. An easy screening method for fungi producing ochratoxin A in pure culture. International Journal of Food Microbiology 71(23): $139-144$.

Dalcero, A., Magnoli, C., Hallak, C., Chiacchiera, S.M., Palacio, G. \& Rosa, C.A. 2002. Detection of ochratoxin A in animal feeds and capacity to produce this mycotoxin by Aspergillus section Nigri in Argentina. Food Additives and Contaminants 19(11): 1065-1072.

Di-Paolo, N., Guarnieri, A. \& Garosi, G. 1994. Inhaled mycotoxins lead to acute renal failure. Nephrology Dialysis Transplantation 9(Suppl. 4): 116-120.

Esteban, A., Abarca, M.L., Bragulat, M.R. \& Cabañes, F.J. 2004. Effects of temperature and incubation time on production of ochratoxin A by black aspergilli. Research in Microbiology 155(10): 861-866.

Ferracin, L., Beatriz, C., Lucia, M., Vieira, C., Monteiro-Vitorello, C.B., Mello, A. \& Fungaro, P.D. 2012. Specific polyketide synthase genes of Aspergillus niger. International Journal of Food Microbiology 155(3): 137-145.

Fredj, S.M.B., Chebil, S. \& Mliki, A. 2009. Isolation and characterization of ochratoxin A and aflatoxin B1 producing fungi infecting grapevines cultivated in Tunisia. African Journal of Microbiology Research 3(9): 523-527.

Frisvad, J.C., Larsen, T.O., De Vries, R., Meijer, M., Houbraken, J., Cabañes, F.J. \& Samson, R.A. 2007. Secondary metabolite profiling, growth profiles and other tools for species recognition and important Aspergillus mycotoxins. Studies in Mycology 59: 31-37.

Gallo, A., Bruno, K.S., Solfrizzo, M., Perrone, G, Mulè, G., Visconti, A. \& Baker, S.E. 2012. New insight into the ochratoxin A biosynthetic pathway through deletion of a nonribosomal peptide synthetase gene in Aspergillus carbonarius. Applied and Environmental Microbiology 78(23): 8208-8218.

Garcia-Cela, E., Crespo-Sempere, A., Ramos, A.J., Sanchis, V. \& Marin, S. 2014. Ecophysiological characterization of Aspergillus carbonarius, Aspergillus tubingensis and Aspergillus niger isolated from grapes in Spanish vineyards. International Journal of Food Microbiology 173: 89-98.

Ghosh, D., Dhar, P., Chakraborty, T., Uddin, N., Das, A.K., North, P.G.S. \& Bengal, W. 2014. Study of aeromycoflora in indoor and outdoor environment of national library, Kolkata. International Journal of Plant, Animal and Environmental Sciences 4: 663-672.

Glass, N.L. \& Donaldson, G.C. 1995. Development of primer sets designed for use with the PCR to amplify conserved genes from filamentous Ascomycetes. Applied and Environmental Microbiology 61(4): 1323-1330.

Hayer, K., Stratford, M. \& Archer, D.B. 2014. Germination of Aspergillus niger conidia is triggered by nitrogen compounds related to L-amino acids. Applied and Environmental Microbiology 80(19): 6046-6053.
Hong, S., Lee, M., Kim, D., Varga, J., Frisvad, J.C., Perrone, G. \& Samson, R.A. 2013. Aspergillus luchuensis, an industrially important black Aspergillus in East Asia. PLOS ONE 8: e63769.

Hong, S., Cho, H., Shin, H., Frisvad, J.C. \& Samson, R.A. 2006. Novel Neosartorya species isolated from soil in Korea. International Journal of Systematic and Evolutionary Microbiology 56(2): 477-486.

Jalili, S., Jinap, S. \& Radu, S. 2010. Natural occurrence of ochratoxin A contamination in commercial black and white pepper products. Mycopathologia 170(4): 251-258.

Kim, D.H., Kim, S.H., Kwon, S.W., Lee, J.K. \& Hong, S.B. 2013. Fungal diversity of rice straw for meju fermentation. Journal of Microbiology and Biotechnology 23(12): 1654-1663.

Kim, N.Y., Lee, I. \& Ji, G.E. 2014. Reliable and simple detection of ochratoxin and fumonisin production in black Aspergillus. Journal of Food Protection 77(4): 653-658.

Kittikamhaeng, N. \& Dachoupakan, C. 2011. Contamination of aflatoxigenic and ochratoxigenic Aspergillus in Thai rice. Proceeding of the 23rd Annual Meeting of the Thai Society for Biotechnology "Systems Biotechnology: Quality \& Success". pp. 144-145.

Lamboni, Y., Nielsen, K.F., Linnemann, A.R., Gezgin, Y.K., Hell, K., Nout, M.J.R. \& Frisvad, J.C. 2016. Diversity in secondary metabolites including mycotoxins from strains of Aspergillus section Nigri isolated from raw cashew nuts from Benin, West Africa. PLoS ONE 11(10): e0164310.

Lasram, S., Oueslati, S., Jouira, H.B., Chebil, S., Mliki, A. \& Ghorbel, A. 2013. Identification of ochratoxigenic Aspergillus section Nigri isolated from grapes by ITS-5.8S rDNA sequencing analysis and in silico RFLP. Journal of Phytopathology 161(4): 280-283.

Leong, S.L., Hocking, A.D. \& Scott, E.S. 2007. Aspergillus species producing ochratoxin A: Isolation from vineyard soils and infection of Semillon bunches in Australia. Journal of Applied Microbiology 102(1): 124-133.

Lopez-Mendoza, M.C., Crespo-Sempere, A. \& MartinezCulebras, P.V. 2009. Identification of Aspergillus tubingensis strains responsible for OTA contamination in grapes and wine based on the acyl transferase domain of a polyketide synthase gene. International Journal of Food Science \& Technology 44(11): 2147-2152.

Magan, N. \& Aldred, D. 2005. Conditions of formation of ochratoxin A in drying, transport and in different commodities. Food Additives \& Contaminants 22(Suppl. 1): 10-16.

Massi, F.P., Sartori, D., Ferranti, L.S., Iamanaka, B.T., Taniwaki, M.H., Vieira, M.L.C. \& Fungaro, M.H.P. 2016. Data on the presence or absence of genes encoding essential proteins for ochratoxin and fumonisin biosynthesis in Aspergillus niger and Aspergillus welwitschiae. Data in Brief 7: 704-708.

Medina, A., Mateo, R., López-ocaña, L., Valle-algarra, M. \& Jiménez, M. 2005. Study of spanish grape mycobiota and ochratoxin a production by isolates of Aspergillus tubingensis and other members of Aspergillus Section Nigri. Applied and Environmental Microbiology 71(8): 4696-4702. 
Nielsen, K.F., Mogensen, J.M., Johansen, M., Larsen, T.O. \& Frisvad, J.C. 2009. Review of secondary metabolites and mycotoxins from the Aspergillus niger group. Analytical and Bioanalytical Chemistry 395(5): 1225-1242.

Nugroho, A.D., Setyabudi, F.M.C., Salleh, B. \& Rahayu, E.S. 2013. Ochratoxigenic black aspergilli isolated from dried agricultural products in Yogyakarta, Indonesia. Journal of Food Science and Engineering 3: 472-480.

Nyongesa, B.W., Okoth, S. \& Ayugi, V. 2015. Identification key for Aspergillus species isolated from maize and soil of Nandi Country, Kenya. Advances in Microbiology 5(4): 205-229.

Palumbo, J.D., O'Keeffe, T.L. \& McGarvey, J.A. 2011. Incidence of fumonisin B2 production within Aspergillus section Nigri populations isolated from California raisins. Journal of Food Protection 74(4): 672-675.

Parenicová, L., Skouboe, P., Frisvad, J., Samson, R.A., Rossen, L., ten Hoor-Suykerbuyk, M. \& Visser, J. 2001. Combined molecular and biochemical approach identifies Aspergillus japonicus and Aspergillus aculeatus as two species. Applied and Environmental Microbiology 67(2): 521-527.

Perrone, G., Mulè, G., Susca, A., Battilani, P., Pietri, A. \& Logrieco, A. 2006. Ochratoxin A production and amplified fragment length polymorphism analysis of Aspergillus carbonarius, Aspergillus tubingensis and Aspergillus niger strains isolated from grapes in Italy. Applied and Environmental Microbiology 72(1): 680-685.

Pettersson, O.V. \& Leong, S.L. 2011. Fungal xerophiles (osmophiles). eLS. Chichester: John Wiley \& Sons Ltd.

Pitt, J.I. \& Hocking, A.D. 2009. Fungi and Food Spoilage. New York: Springer.

Priyanka, S.R., Venkataramana, M., Kumar, G.P., Rao, V.K., Murali, H.C.S. \& Batra, H.V. 2014. Occurrence and molecular detection of toxigenic Aspergillus species in food grain samples from India. Journal of the Science of Food and Agriculture 94(3): 537-543.

Rahmani, A., Jinap, S. \& Soleimany, F. 2010. Validation of the procedure for the simultaneous determination of aflatoxins ochratoxin A and zearalenone in cereals using HPLC-FLD. Food Additives \& Contaminants. Part A, Chemistry, Analysis, Control, Exposure \& Risk Assessment 27(12): 1683-1693.

Richard, J.L., Plattner, R.D., May, J. \& Liska, S.L. 1999. The occurrence of ochratoxin A in dust collected from a problem household. Mycopathologia 146(2): 99-103.

Saadabi, A.M. 2011. Prevalence and assessment of air-borne fungi at vegetable central market of Khartoum State, Sudan. Journal of Applied Sciences Research 7(5): 550-553.

Saadullah, A.A.M. 2013. Identification and determination of aflatoxin $\mathrm{G} 1$ and aflatoxigenic Aspergillus isolates from dried vine in Duhok by LC/MS-MS technique. Journal of Basrah Researches (Sciences) 39(1): 66-74.

Samson, R.A., Noonim, P., Meijer, M., Houbraken, J., Frisvad, J.C. \& Varga, J. 2007. Diagnostic tools to identify black Aspergilli. Studies in Mycology 59: 129-145.

Samson, R.A., Visagie, C.M., Houbraken, J., Hong, S.B., Hubka, V., Klaassen, C.H.W. \& Frisvad, J.C. 2014. Phylogeny, identification and nomenclature of the genus Aspergillus. Studies in Mycology 78: 141-173.
Samsudin, N.I.P. \& Abdullah, N. 2013. A preliminary survey on the occurrence of mycotoxigenic fungi and mycotoxins contaminating red rice at consumer level in Selangor, Malaysia. Mycotoxin Research 29(2): 89-96.

Sánchez-Hervás, M., Gil, J.V., Bisbal, F., Ramón, D. \& MartínezCulebras, P.V. 2008. Mycobiota and mycotoxin producing fungi from cocoa beans. International Journal of Food Microbiology 125(3): 336-340.

Schatzmayr, G. \& Streit, E. 2013. Global occurrence of mycotoxins in the food and feed chain: Facts and figures. World Mycotoxin Journal 6(3): 213-222.

Serra, R., Caban, F.J., Perrone, G. \& Castella, G. 2006. Aspergillus ibericus: A new species of section Nigri isolated from grapes. Mycologia 98(2): 295-306.

Shehu, K. \& Muhammad, S. 2012. Fungi associated with storage rots of onion bulbs in Sokoto, Nigeria. International Journal of Modern Botany 1(1): 1-3.

Soleimany, F., Jinap, S. \& Abas, F. 2012. Determination of mycotoxins in cereals by liquid chromatography tandem mass spectrometry. Food Chemistry 130(4): 1055-1060.

Spadaro, D., Patharajan, S., Lorè, A., Garibaldi, A. \& Gullino, M.L. 2012. Ochratoxigenic black species of aspergilli in grape fruits of northern Italy identified by an improved PCR-RFLP procedure. Toxins 4(2): 42-54.

Storari, M., Bigler, L., Gessler, C. \& Broggini, G.A.L. 2012. Assessment of the ochratoxin A production ability of Aspergillus tubingensis. Food Additives \& Contaminants. Part A, Chemistry, Analysis, Control, Exposure \& Risk Assessment 29(9): 1450-1454.

Susca, A., Proctor, R.H., Morelli, M., Haidukowski, M., Gallo, A., Logrieco, A.F. \& Moretti, A. 2016. Variation in fumonisin and ochratoxin production associated with differences in biosynthetic gene content in Aspergillus niger and $A$. welwitschiae isolates from multiple crop and geographic origins. Frontiers in Microbiology 7(1412): 1-15.

Tamura, K., Peterson, D., Peterson, N., Stecher, G., Nei, M. \& Kumar, S. 2011. MEGA5: Molecular evolutionary genetics analysis using maximum likelihood, evolutionary distance, and maximum parsimony methods. Molecular Biology and Evolution 28(10): 2731-2739.

Teh, L.Y. \& Latiffah, Z. 2015. Occurrence and molecular characterization of Aspergillus species in beach sand. Malaysian Applied Biology 44(2): 119-127.

Varga, J., Kocsube, S., Szigeti, G., Baranyi, N., Vagvlogyi, C., Despot, D.J. \& Klaric, M.S. 2014. Occurrence of black Aspergilli in indoor environments of six countries. Archives of Industrial Hygiene and Toxicology 65: 219-223.

Varga, J., Frisvad, J.C., Kocsubé, S., Brankovics, B., Tóth, B., Szigeti, G. \& Samson, R.A. 2011. New and revisited species in Aspergillus section Nigri. Studies in Mycology 69(1): 1-17.

Vitale, A., Cirvilleri, G., Panebianco, A., Epifani, F., Perrone, G. \& Polizzi, G. 2012. Molecular characterisation and pathogenicity of Aspergillus section Nigri causing Aspergillus vine canker of table grapes in Italy. European Journal of Plant Pathology 132: 483-487. 
Wardah, A.R., Hafizi, R., Baharuddin, S.N. \& Salleh, B. 2012. Incidence and remediation of fungi in a sick building in Malaysia: A case study. Aerobiologia 28: 275-283.

White, T.J., Bruns, T. \& Taylor, J. 1990. Amplification and direct sequencing of fungal ribosomal RNA genes for phylogenetics. In PCR Protocols: A Guide to Methods and Applications, edited by Innis, M.A., Gelfand, D.H., Sninsky, J.J. \& White, T.J. New York: Academic Press. pp. 315-322.

Zarei, F., Mirhendi, H., Motamedi, M., Ahmadi, B., NouripourSisakht, S., Zarrinfar, H. \& Hashemi, J. 2016. Black Aspergillus species isolated from clinical and environmental samples in Iran. Journal of Medical Microbiology 64(11): 1454-1456.
Zheng, M.Z., Richard, J.L. \& Binder, J. 2006. A review of rapid methods for the analysis of mycotoxins. Mycopathologia 161: 261-273.

School of Biological Sciences

Universiti Sains Malaysia

11800 USM, Penang

Malaysia

*Corresponding author; email: Lfah@usm.my

Received: 28 July 2020

Accepted: 17 May 2021 